\title{
Kemampuan Representasi Simbolik Mahasiswa Calon Guru dalam Menyelesaikan Masalah Matematika Ditinjau dari Perbedaan Gender
}

\author{
Putri Ayu Kusgiarohmah ${ }^{1}$, Sudirman ${ }^{2}$, dan Swasono Rahardjo ${ }^{3}$ \\ 1, 2, 3 Program Studi Pendidikan Matematika, Fakultas Matematika dan Ilmu Pengetahuan Alam Universitas Negeri Malang, \\ Jl. Semarang 5, Malang, Indonesia \\ ayuputrikusgiarohmah@gmail.com
}

\begin{abstract}
BNSP has set teacher professionalism standards in teaching. These standards include, among others, that teachers are required to master the material, conceptual structure, and scientific mindset that can support the mathematics learning process. The teacher's professional standards are intended so that teachers are able to assist and guide students in achieving their learning goals. However, the results of observations of prospective mathematics teacher students at a university in Malang show that they still have difficulty in making mathematical representations. Therefore, this research was conducted to describe the symbolic representation ability of prospective teacher students in terms of gender differences. Gender differences in this study are to describe whether gender differences can affect a person's ability to make mathematical representations. A mixed methods approach with quantitative descriptive research was chosen to describe the research objectives. Data were collected through documentation and test activities. The test was given to 35 student teacher candidates majoring in Mathematics Education at one of the universities in Malang. A total of 4 students consisting of 2 female students and 2 male students were selected to be studied in more detail. The results showed that female students were more tenacious and thorough in solving mathematical problems. They are able to make a symbolic representation of a given problem. Female students also make interpretations of the symbols used in problem solving. Unlike the male students. They are more likely to directly input the numbers contained in the problem into problem solving algorithm.
\end{abstract}

Keywords: Gender, Mathematical Problems, Symbolic Representation

\begin{abstract}
Abstrak
BNSP telah mengatur standar profesionalitas guru dalam mengajar. Standar tersebut antara lain, guru wajib menguasai materi, struktur konsep, dan pola pikir keilmuan yang dapat mendukung proses pembelajaran matematika. Standar profesionalitas guru tersebut ditujukan agar guru mampu membantu dan membimbing peserta didik dalam mencapai tujuan belajarnya. Namun, hasil observasi mahasiswa calon guru matematika di salah satu universitas yang berada di Malang menunjukkan jika mereka masih mengalami kesulitan dalam membuat representasi matematis. Oleh karena itu penelitian ini dilakukan untuk mendeskripsikan kemampuan representasi simbolik mahasiswa calon guru ditinjau dari perbedaan gender. Perbedaan gender dalam penelitian ini untuk mendeskripsikan apakah perbedaan gender dapat mempengaruhi kemampuan seseorang dalam membuat representasi matematis. Pendekatan Mixed Methods dengan jenis penelitian deskriptif kuantitatif dipilih untuk menjabarkan tujuan penelitian. Data dikumpulkan melalui kegiatan dokumentasi dan tes. Tes diberikan kepada 35 mahasiswa calon guru dengan jurusan Pendidikan Matematika di salah satu universitas yang ada di Malang. Sebanyak 4 mahasiswa yang terdiri dari 2 mahasiswa perempuan dan 2 mahasiswa laki-laki dipilih untuk dikaji lebih rinci. Hasil penelitian menunjukkan bahwa mahasiswa perempuan lebih ulet dan teliti dalam menyelesaikan masalah matematis. Mereka mampu membuat representasi simbolik dari masalah yang diberikan. Mahasiswa perempuan juga membuat interpretasi dari simbol-simbol yang digunakan dalam selesaian masalah. Berbeda dengan mahasiswa laki-laki. Mereka lebih cenderung langsung menginputkan bilangan-bilangan yang termuat di soal kedalam algoritma selesaian masalah.
\end{abstract}

Kata kunci: Gender, Masalah Matematis, Representasi Simbolik

Copyright (c) 2022 Putri Ayu Kusgiarohmah, Sudirman, Swasono Rahardjo $\triangle$ Corresponding author: Putri Ayu Kusgiarohmah

Email Address: ayuputrikusgiarohmah@gmail.com (Kedung Bogo, Kuwik, Kunjang, Kediri, Jawa Timur) Received 23 November 2021 Accepted 25 January 2022, Published 02 February 2022

\section{PENDAHULUAN}

Guru memiliki peran penting dalam menentukan kualitas peserta didik. Profesionalitas guru dalam membimbing peserta didik dalam kelas dapat terlaksana jika guru mampu menciptakan 
lingkungan belajar yang kondusif. Guru sebagai pendamping proses pembelajaran di kelas hendaknya mampu menguasai konten, mampu memberikan motivasi, dan memberikan dukungan kepada peserta didik agar mampu mencapai tujuan pembelajaran. Untuk itu guru harus mempunyai standar kompetensi dan mutu yang berkualitas untuk membantu peserta didik memenuhi standar mutu pendidikan (Sukmawati, 2019).

Guru yang berkualitas didasari oleh calon guru yang berkualitas pula. Calon guru selama menempuh masa studi perkuliahan dibimbing dan dibekali ilmu sebagai modal untuk menjadi guru yang professional. Mahasiswa calon guru dipersiapkan memenuhi standar kualifikasi akademik dan kompetensi guru yang telah ditetapkan oleh Badan Nasional Standar Pendidikan (BNSP) (2007), diantaranya guru harus memiliki kompetensi pedagogik, kompetensi kepribadian, kompetensi sosial, dan kompetensi professional.

Kompetensi professional dalam BNSP menuntut guru harus menguasai materi, struktur konsep, dan pola pikir keilmuan yang mendukung proses pembelajaran matematika. Sehingga secara tidak langsung, selama menempuh perkuliahan, mahasiswa calon guru perlu mempersiapkan diri untuk memenuhi standar kompetensi tersebut. Namun berdasarkan observasi di lapangan terhadap mahasiswa Pendidikan Matematika di salah satu Universitas yang berada di Malang terlihat bahwa mahasiswa masih mengalami kesulitan dalam menguasai konten yang sedang diajarkan di perkuliahan. Kendala yang sering dialami mahasiswa calon guru salah satunya yaitu melakukan kesalahan dalam membuat representasi matematis.

Sanjaya dkk., (2018) menjelaskan bahwa representasi matematis merupakan kemampuan siswa menggunakan ungkapan-ungkapan dari ide matematisnya yang ditampilkan dalam bentuk model. Representasi merupakan alat yang digunakan siswa dalam memahami situasi tertentu dan menyatakan pemikirannya dengan menggunakan kombinasi informasi tertulis, fisik, benda, atau pengaturan pikiran yang dibangun dengan teliti (Sokolowski, 2018). Representasi matematis dapat dilakukan dengan menggunakan berbagai interpretasi seperti kata-kata atau verbal, tulisan, gambar, tabel, grafik, benda konkrit, simbol matematika, dan lain sebagainya (Sabirin, 2014). Sehingga dapat disimpulkan bahwa representasi matematis merupakan kemampuan siswa dalam menggambarkan ungkapan dan ide matematik dengan menggunakan tulisan, gambar, verbal, tabel, grafik, simbol matematis, dan lain sebagainya.

Representasi matematis terdiri dari representasi verbal, representasi visual, dan representasi simbolik (Sanjaya dkk., 2018). Representasi verbal merupakan penyampaian ide-ide matematika dengan menggunakan kata-kata atau lisan. Representasi visual merupakan bentuk penyampaian ideide matematika secara tertulis dengan menggunakan gambar, grafik, model, atau yang lainnya. Representasi simbolik merupakan bentuk penyampaian ide-ide matematis dengan menggunakan pernyataan matematis/notasi matematis, numerik, atau simbol-simbol aljabar (Anwar \& Rahmawati, 2017; Aryanti dkk., 2013). 
Representasi simbolik atau deskriptif biasanya digunakan untuk mengekspresikan informasi abstrak (Sokolowski, 2018). Umumnya, pengetahuan simbolik tidak dianggap sebagai aspek penting dari proses pembelajaran. Padahal pengetahuan tersebut menjadi landasan penting dalam mempelajari suatu konsep matematika. Indikator dari representasi simbolik menurut Suryana (2012) yaitu mahasiswa dikatakan memiliki representasi simbolik jika mereka mampu membuat persamaan atau model matematika dari representasi lain yang diberikan, membuat konjektur dari suatu pola bilangan, dan menyelesaikan masalah dengan melibatkan ekspresi matematis. Indikator tersebut diadaptasi dan dijadikan pedoman dalam melakukan analisis kemampuan mahasiswa calon guru dalam membuat representasi simbolik ketika menyelesaikan masalah penerapan sifat-sifat counting pada himpunan hingga. Sehingga indikator representasi simbolik yang digunakan dalam penelitian ini disajikan dalam tabel 1 sebagai berikut:

Tabel 1. Indikator Representasi Simbolik dalam Menyelesaikan Masalah Penerapan Sifat-Sifat Counting pada Himpunan Hingga

\begin{tabular}{|cl|l|}
\hline \multicolumn{2}{|c|}{ Kategori } & \multicolumn{1}{c|}{ Indikator } \\
\hline 1. $\begin{array}{l}\text { Membuat persamaan atau model matematika } \\
\text { dari representasi lain yang diberikan }\end{array}$ & $\begin{array}{l}\text { Membuat representasi simbolik dari masalah } \\
\text { matematis yang diberikan }\end{array}$ \\
\hline 2. & Membuat konjektur dari suatu pola bilangan. & $\begin{array}{l}\text { Memilih formula counting yang sesuai dengan } \\
\text { permasalahan yang diberikan }\end{array}$ \\
\hline $\begin{array}{l}\text { 3. } \\
\text { Menyelesaikan masalah dengan melibatkan } \\
\text { ekspresi matematis }\end{array}$ & $\begin{array}{l}\text { Menyelesaikan masalah matematis } \\
\text { menggunakan representasi simbolik yang telah } \\
\text { dibuat }\end{array}$ \\
\hline
\end{tabular}

Penelitian dari Aliyanti dkk., (2019) menyatakan bahwa mahasiswa calon guru mengalami kesalahan representasi simbolik dalam mengerjakan soal HOTS dengan materi turunan parsial disebabkan karena mahasiswa belum memahami simbol-simbol turunan parsial. Pemahaman mahasiswa mengenai simbol-simbol matematika berperan dalam menentukan hasil akhir dari penyelesaian masalah matematika. Hasil penelitian tersebut sesuai dengan hasil observasi yang dilakukan di lapangan.

Kebanyakan mahasiswa menulis ulang pertanyaan yang terdapat dalam soal dan memasukkan bilangan-bilangan yang termuat dalam soal. Mahasiswa belum membuat simbolisasi dari permasalahan yang diberikan dan langsung melakukan prosedur perhitungan untuk menentukan hasil akhir. Padahal transformasi soal kedalam simbol matematika dibutuhkan dalam menyelesaikan permasalahan matematik. Pernyataan ini didukung oleh hasil penelitian yang dilakukan oleh Fridgo dkk., (2016) yang menyatakan bahwa penyebab mahasiswa melakukan kesalahan dalam membuat representasi matematis karena kurangnya kemampuan dalam mentransformasikan informasi yang termuat dalam soal secara simbolik. Hal itu berdampak pada ketidakmampuan siswa dalam menggunakan formulasi matematika yang tepat sesuai dengan permasalahan yang diberikan. Pernyataan tersebut juga sesuai dengan temuan dari Damayanti \& Firmansyah (2019). Menurutnya, 
mahasiswa mengalami kesulitan dalam menyelesaikan permasalahan matematis disebabkan karena mereka belum menggunakan representasi dengan tepat, salah satunya yaitu mahasiswa belum mampu membuat persamaan atau model matematis untuk menggambarkan ide-ide matematikanya.

Penelitian ini bertujuan untuk melanjutkan penelitian dari Aliyanti dkk., (2019) dengan menggunakan instrumen yang berbeda dan kebaruan dari penelitian ini terletak pada perbedaan gender. Gender dalam berbagai perspektif memiliki andil dalam mengukur perbedaan keterampilan tertentu. Umumnya, perempuan lebih telaten dan mahir dalam mengerjakan tugas-tugas tertulis dan membaca sedangkan laki-laki lebih unggul dalam bidang matematika (Purwanti, 2013; Ulpa, 2014). Penelitian secara psikologis pun menunjukkan hal yang serupa, namun kenyataan dilapangan tidak sedikit perempuan yang berprestasi di matematika. Aspek unggul dalam bermatematika menunjukkan perbedaan jika dihubungkan dengan penyelesaian soal spatial. Laki-laki memiliki pengalaman spatial yang lebih tinggi dan perempuan lebih unggul dalam kemampuan komunikasi verbal, lebih termotivasi, dan terorganisasi dalam belajar (MZ, 2013). Sedangkan jika dilihat secara umum, perbedaan tersebut tidak selalu nampak. Salah satunya Hardy dkk., (2015) menyatakan bahwa gender tidak mempengaruhi kemampuan siswa dalam melakukan pemecahan masalah. Merujuk uraian tersebut, penelitian ini dilakukan untuk meninjau kemampuan representasi simbolik yang dilakukan mahasiswa calon guru dalam menyelesaikan masalah matematika ditinjau dari perbedaan gender.

\section{METODE}

Pendekatan mixed method dengan jenis penelitian deskriptif kuantitatif digunakan untuk mendeskripsikan kemampuan mahasiswa calon guru dalam membuat representasi simbolik ditinjau dari perbedaan gender. Pemilihan subjek penelitian didasarkan pada kriteria sebagai berikut, a) subjek merupakan mahasiswa pendidikan matematika, b) subjek yang dipilih telah mengikuti mata kuliah Landasan Matematika, c) subjek yang dipilih telah mempelajari materi sifat-sifat counting pada himpunan hingga, d) subjek yang dipilih berjenis kelamin laki-laki atau perempuan. Oleh karena itu, subjek dalam penelitian ini merupakan mahasiswa semester 1 program studi Pendidikan Matematika di salah satu universitas yang berada di Malang. Subjek terdiri dari dua mahasiswa perempuan dan dua mahasiswa laki-laki.

Prosedur yang dilakukan dalam penelitian ini yaitu peneliti melakukan studi pendahuluan guna mencari permasalahan yang terjadi di lapangan. Berdasarkan hasil studi pendahuluan tersebut ditemukan bahwa masih ada mahasiswa yang tidak menuliskan simbol sesuai dengan aturan matematika. Tahapan kedua yaitu melakukan studi literatur terkait permasalahan yang ditemukan di lapangan. Tahapan ketiga yaitu menentukan subjek penelitian yang sesuai dengan tujuan penelitian. Pada tahapan ini dilakukan uji homogenitas untuk memastikan subjek yang diambil memiliki kemampuan matematika yang sama. Tahapan keempat yaitu menentukan metode yang digunakan untuk mengumpulkan data penelitian, dimana pada penelitian ini menggunakan metode tes. Tahapan kelima yaitu melakukan penelitian sesuai dengan rancangan yang telah dibuat. Tahapan keenam yaitu 
melakukan analisis data mengenai kemampuan representasi simbolik yang dilakukan mahasiswa calon guru dan mengelompokkannya berdasarkan gender mahasiswa. Tahapan ketujuh yaitu menulis dan melaporkan hasil penelitian yang telah dilakukan secara deskriptif kualitatif.

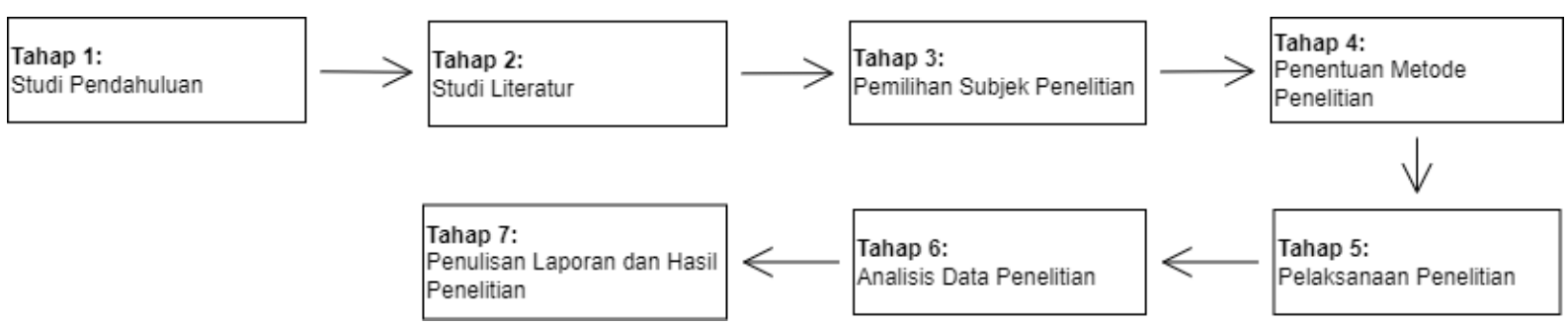

Gambar 1. Diagram Alur Penelitian

Pemberian tes kepada mahasiswa dilakukan sebagai teknik dalam menghimpun data penelitian. Tes yang diberikan kepada mahasiswa berupa soal uraian mengenai penerapan sifat-sifat counting pada himpunan hingga. Soal tes diambil dari buku karya Morash (1987) yang berjudul "Bridge to Abstract Mathematic: Mathematical Proof \& Structures". Sebelum diberikan ke subjek penelitian, soal-soal tes dialih bahasa ke bahasa Indonesia dan di validasi oleh dosen Pendidikan Matematika. Analisis tes ini dilakukan dengan berpedoman pada indikator representasi simbolik yang telah tersaji dibagian pendahuluan.

Teknik analisis data dalam penelitian ini diawali dengan melakukan reduksi data. Sebanyak 35 data mahasiswa yang mengerjakan tes, diambil sebanyak 4 mahasiswa yang mewakili dua mahasiswa laki-laki dan dua mahasiswa perempuan untuk dikaji lebih rinci. Data disortir berdasarkan kejelasan dalam melakukan penulisan dan bukan tergolong jawaban yang terindikasi mencontek.

Setelah tahap reduksi data dilalui, selanjutnya data tersebut dianalisis dan disajikan dalam bentuk deskriptif kualitatif. Data yang disajikan berupa kemampuan mahasiswa dalam membuat representasi simbolik dan penggunaan ekspresi matematis berdasarkan perbedaan gender. Data yang telah dianalisis ditinjau kembali menggunakan penelitian terdahulu untuk memverifikasi bahwa temuan tersebut valid. Tahapan terakhir yaitu penarikan kesimpulan terhadap temuan yang diperoleh dari penelitian yang telah dilakukan.

\section{HASIL DAN DISKUSI}

\section{Hasil Uji Homogenitas}

Uji homogenitas pada penelitian ini dilakukan untuk memastikan subjek penelitian yang dipilih memiliki tingkat kemampuan matematika yang setara. Data uji homogenitas diambil dari nilai hasil belajar matematika 35 mahasiswa calon guru. Uji homogenitas dilakukan dengan berbantuan aplikasi SPSS dengan hasil uji sebagai berikut: 


\section{Test of Homogeneity of Variance}

\begin{tabular}{|c|c|c|c|c|c|}
\hline & & $\begin{array}{l}\text { Levene } \\
\text { Statistic }\end{array}$ & df1 & $\mathrm{df2}$ & Sig. \\
\hline \multirow[t]{4}{*}{ Nilai } & Based on Mean & .026 & 1 & 33 & .874 \\
\hline & Based on Median & .023 & 1 & 33 & .880 \\
\hline & $\begin{array}{l}\text { Based on Median and } \\
\text { with adjusted df }\end{array}$ & .023 & 1 & 29.224 & .880 \\
\hline & Based on trimmed mean & .020 & 1 & 33 & .889 \\
\hline
\end{tabular}

Gambar 2. Hasil Uji Homogenitas Hasil Belajar Matematika Mahasiwa Calon Guru

Hasil uji homogenitas tersebut menunjukkan bahwa nilai signifikan based on Mean sebesar 0,874, artinya nilai signifikan $>0,005$. Oleh karena itu dapat disimpulkan jika ke 35 mahasiswa calon guru memiliki kemampuan matematika yang sama.

\section{Kemampuan Representasi Simbolik Mahasiswa Calon Guru}

Penjabaran kesalahan representasi simbolik yang dilakukan mahasiswa calon guru didasarkan pada analisis yang lebih rinci terhadap 4 mahasiswa Pendidikan Matematika ketika menyelesaikan tes soal uraian tentang penerapan sifat-sifat counting pada himpunan hingga. Gambar 1 dan Gambar 3 merupakan hasil pengerjaan mahasiswa perempuan. Sedangkan Gambar 2 dan Gambar 4 merupakan hasil pengerjaan mahasiswa laki-laki.

Hasil analisis pengerjaan mahasiswa perempuan dan laki-laki dalam menyelesaikan masalah penerapan sifat-sifat counting pada himpunan hingga yang berbunyi "34 fakultas di Perguruan Tinggi lokal telah menginvestasikan dana pensiunannya baik dalam dana saham atau dana pasar uang. Terdapat 22 fakultas menginvestasikannya dalam bentuk dana saham dan 27 fakultas menginvestasikannya dalam bentuk dana pasar uang. Berapa banyak yang telah menginvestasikan sebagian dana pensiunan mereka di kedua reksa dana?" disajikan sebagai berikut.

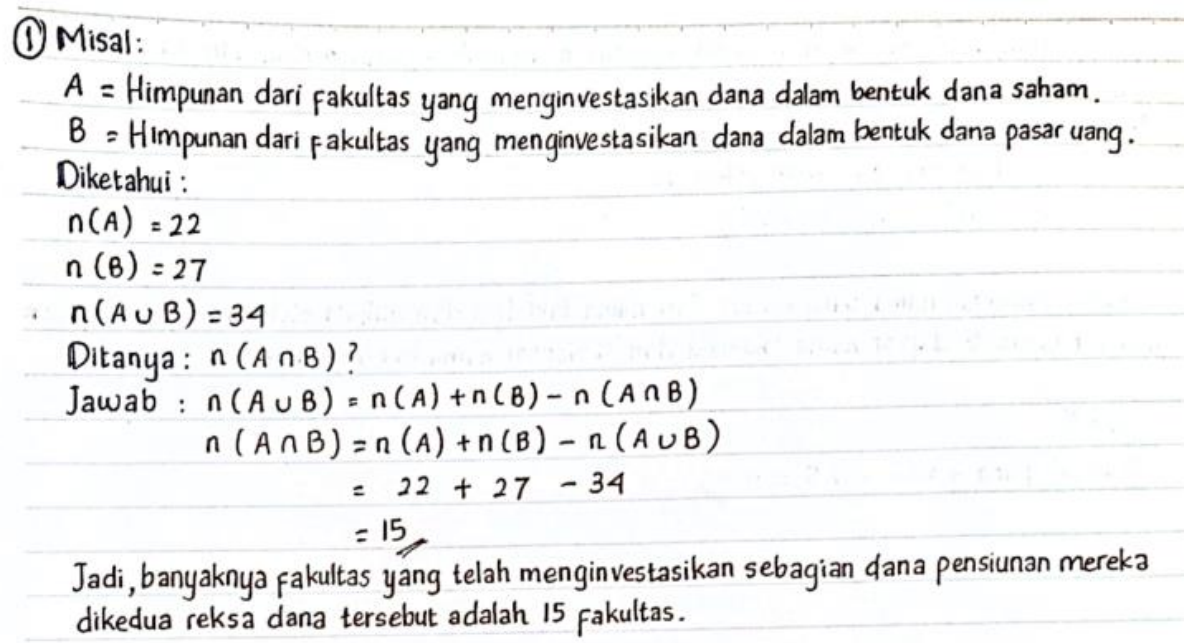

Gambar 3. Hasil Pengerjaan Mahasiswa Perempuan (P1) pada Masalah Matematis yang Pertama 
Gambar 3 menunjukkan bahwa subjek P1 telah membuat representasi simbolik dari masalah yang diberikan. Dia memisalkan A sebagai himpunan dari fakultas yang menginvestasikan dana dalam bentuk dana saham dan memisalkan B sebagai himpunan dari fakultas yang menginvestasikan dana dalam bentuk dana pasar uang. Penggunaan notasi matematis yang digunakan subjek P1 juga sudah tepat. Pada indikator kesesuaian formula counting dengan masalah yang diberikan juga menunjukkan bahwa P1 telah memahami masalah tersebut. Hal itu sesuai dengan Morash (1987) yang menyatakan bahwa untuk mengetahui banyaknya elemen dari gabungan dua himpunan dapat menggunakan counting formula 1 yang berbunyi "Jika $A$ dan $B$ merupakan himpunan hingga, maka $n(A \cup B)=n(A)+n(B)-n(A \cap B)$ ". Gambar 3 juga menunjukkan bahwa P1 dapat menyelesaikan masalah matematis yang diberikan. Dia dapat menemukan bahwa banyaknya fakultas yang investasi di kedua reksa dana yaitu 15 fakultas. P1 juga mampu menarik kesimpulan dari proses pengerjaan yang dilakukan. Artinya P1 telah memenuhi indikator yang ketiga, yaitu mampu menyelesaikan masalah matematis dari masalah simbolik yang telah diberikan.

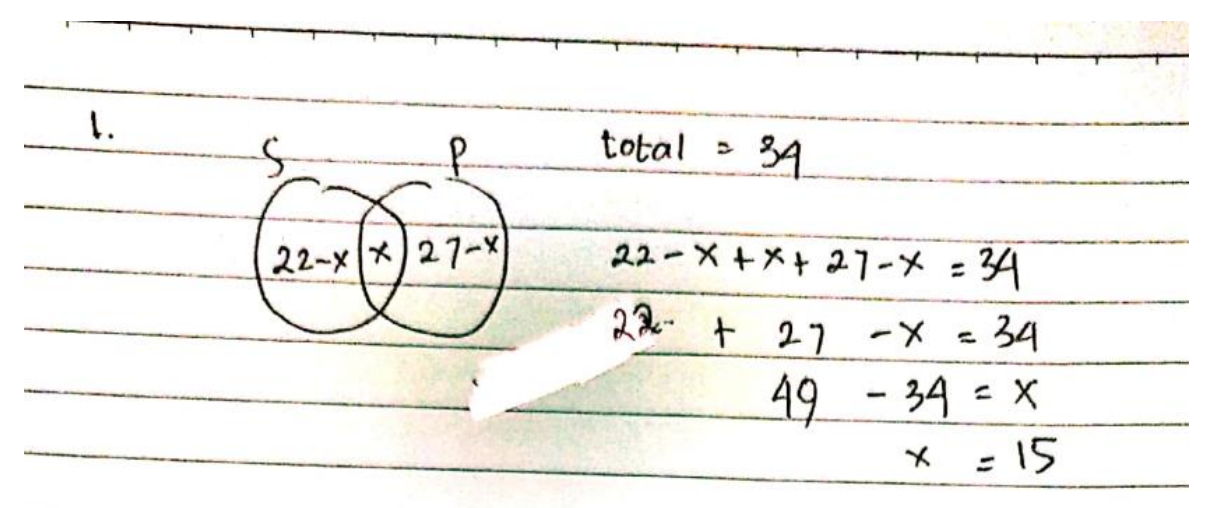

Gambar 4. Hasil Pengerjaan Mahasiswa Laki-Laki (L1) pada Masalah Matematis yang Pertama

Gambar 4 menunjukkan hasil pengerjaan yang dilakukan oleh subjek L1. Pada gambar tersebut terlihat bahwa L1 tidak menjelaskan simbol-simbol yang digunakan dalam algoritma selesaian masalah. L1 langsung melakukan perhitungan menggunakan bilangan-bilangan yang telah diketahui dalam soal. Hal itu menunjukkan bahwa L1 belum memenuhi indikator representasi simbolik yaitu membuat representasi simbolik dari masalah matematis yang diberikan. Selanjutnya, untuk indikator representasi simbolik tentang kesesuaian formula counting terhadap masalah yang diberikan, L1 menyelesaikan masalah tersebut tanpa menggunakan sifat-sifat counting pada himpunan hingga. Dia menyelesaikan soal menggunakan metode lain diluar konteks materi yang sedang diajarkan, artinya L1 belum memahami instruksi soal. Meskipun L1 mampu menyelesaikan masalah dengan tepat, namun jika dia tidak mengikuti instruksi soal dengan baik akan berdampak pada kesulitan guru dalam menganalisis pemahaman siswa terhadap materi yang sedang diajarkan. 
Hasil analisis pengerjaan mahasiswa perempuan dan laki-laki dalam menyelesaikan masalah penerapan sifat-sifat counting pada himpunan hingga yang berbunyi "Berapa banyak himpunan dari sepuluh jawaban untuk menjawab sepuluh pertanyaan dalam tes benar-salah?" disajikan sebagai berikut.

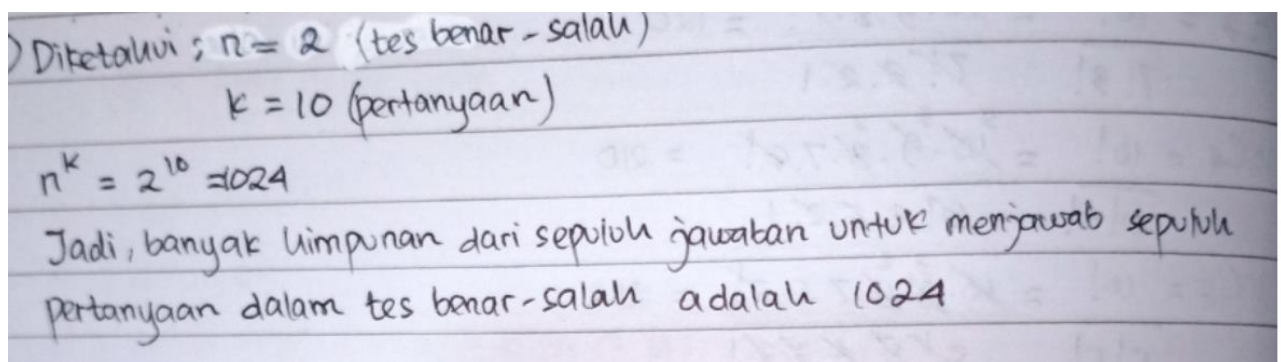

Gambar 5. Hasil Pengerjaan Mahasiswa Perempuan (P2) pada Masalah Matematis yang Kedua

Gambar 5 menunjukkan bahwa P2 telah membuat representasi simbolik dari masalah matematis yang diberikan. Hanya saja bahasa yang digunakan belum sesuai dengan aturan matematika. Seharusnya P2 menuliskan $n$ sebagai banyaknya pilihan jawaban, dimana pada masalah tersebut pilihan jawaban yang tersedia terdapat dua kemungkinan yaitu benar dan salah. Sehingga nilai $n=2$. Sedangkan $k$ seharusnya dijelaskan sebagai interpretasi dari banyaknya pertanyaan yang tersedia, dimana dalam masalah tersebut terdapat 10 pertanyaan yang harus diselesaikan, artinya nilai $k=10$. Kasus tersebut menunjukkan bahwa P2 belum mampu membuat representasi simbolik dari masalah matematis yang diberikan secara tepat. Namun dari segi kesesuaian formula counting dalam menyelesaikan masalah yang diberikan, P2 sudah mampu memilih formula dengan tepat. Berdasarkan buku karya Morash (1987), untuk mengetahui banyaknya susunan $k$ objek yang dapat dibentuk dari himpunan $n$ objek, jika tidak ada batasan jumlah penggunaan masing-masing $n$ objek dalam susunan, maka rumus penghitungannya adalah $n^{k}$. Gambar 4 juga menunjukkan bahwa P2 mampu melakukan prosedur perhitungan sesuai dengan aturan matematika dan mampu menarik kesimpulan dari prosedur perhitungan yang dilakukan. Artinya P2 memenuhi indikator representasi simbolik yang ketiga yaitu menyelesaikan masalah yang diberikan menggunakan representasi simbolik yang telah dibuat.

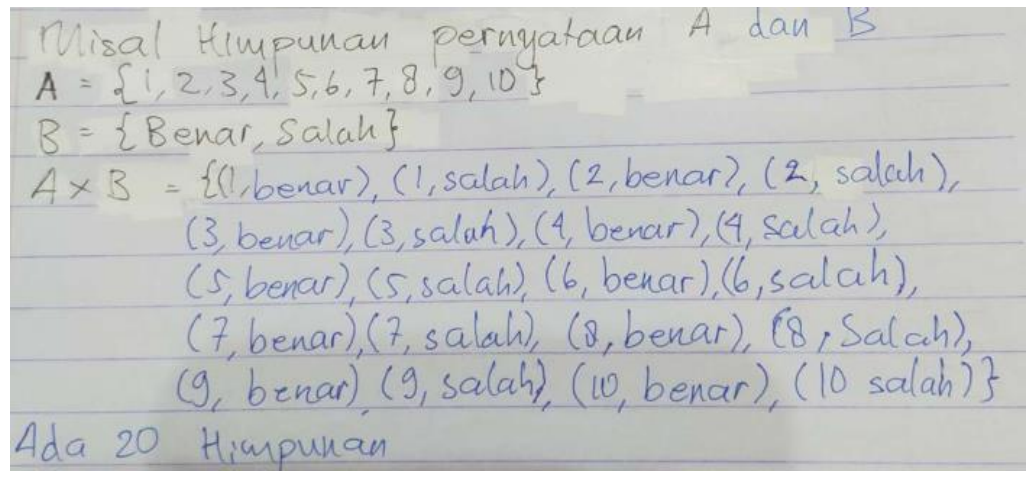

Gambar 6. Hasil Pengerjaan Mahasiswa Laki-Laki (L2) pada Masalah Matematis yang Kedua 
Hasil pengerjaan L2 pada gambar 6 menunjukkan bahwa L2 belum menginterpretasikan simbol $A$ dan $B$ yang ia gunakan. Dia langsung menuliskan $A$ merupakan himpunan dari bilangan asli kurang dari 11 dan $B=\{$ benar, salah $\}$. Seharusnya sebelum menulis seperti itu, L2 harus menjelaskan terlebih dahulu interpretasi dari simbol-simbol yang digunakan untuk membuat ekspresi matematis. Hal ini menunjukkan bahwa L2 belum membuat representasi simbolik dari masalah yang diberikan karena dia belum memahami cara mentransformasikan pernyataan matematis secara simbolik. Strategi yang digunakan untuk menyelesaikan masalah tersebut yaitu dengan medaftar pasangan berurutan yang mungkin terjadi. Artinya L2 belum menerapkan sifat-sifat counting pada himpunan hingga. Hasil pengerjaan L2 juga belum tepat. Hasil akhir yang ia temukan yaitu terdapat 20 himpunan. Padahal jawaban yang benar yaitu terdapat 1.024 himpunan. Jika dilihat lebih rinci, L2 belum menuliskan semua pasangan berurutan yang mungkin terjadi. Artinya L2 belum mampu menyelesaikan masalah matematis menggunakan representasi simbolik yang telah dibuat karena kurang teliti dan belum memahami soal dengan benar.

Temuan-temuan tersebut menunjukan bahwa mahasiswa perempuan lebih unggul dalam menuliskan simbol dan notasi. Umumnya mereka menuliskan interpretasi dari simbol-simbol yang digunakan sebelum berlanjut ke perhitungan. Mahasiswa perempuan mampu membuat alur pemikirannya mudah dipahami oleh orang lain. Hasil ini sejalan dengan penelitian yang dilakukan oleh Pane dkk., (2018) yang menyatakan bahwa mahasiswa yang mampu menuliskan notasi dan simbol-simbol matematika mengindikasikan bahwa ia telah mampu menyampaikan alur pemikirannya. Berbeda dengan mahasiswa laki-laki yang cenderung berfokus pada hasil akhir saja. Hal itu dikarenakan perempuan lebih unggul dalam penggunaan tata bahasa, membaca, dan menulis, sedangkan laki-laki lebih dominan dalam hal melakukan perhitungan matematis (Susilowati, 2016).

Perbedaan mahasiswa perempuan dan laki-laki pada indikator yang kedua menunjukkan bahwa mahasiswa perempuan cenderung berpaku pada apa yag sedang mereka pelajari. Sedangkan mahasiswa laki-laki cenderung berpikir secara luas dan menggunakan pengetahuan yang diperoleh sebelumnya. Hal itu dikarenakan terdapat perbedaan cara mengoperasikan otak masing-masing. Perempuan dan laki-laki menggunakan bagian otak yang berbeda ketika melakukan kegiatan mengingat, merasakan emosi, mengenali lingkungan sekitar, memecahkan masalah, mempelajari sesuatu, dan pengambilan keputusan (Anwar dkk., 2019).

Ketika menyelesaikan masalah, tidak ada perbedaan yang signifikan diantara keduanya. Meskipun dari sampel yang dijabarkan menunjukkan bahwa mahasiswa perempuan lebih unggul dibanding mahasiswa laki-laki. Pada penelitian ini menunjukkan faktor yang menyebabkan perempuan lebih unggul dibanding mahasiswa laki-laki karena tingkat ketelitian yang berbeda. Mahasiswa perempuan lebih teliti karena cara menuliskan algoritma perhitungannya juga sistematis. Davita \& Pujiastuti (2020) memiliki kesimpulan yang sama. Hasil penelitiannya menunjukkan bahwa perempuan lebih ungul dalam memecahkan masalah matematika dibanding laki-laki. Meskipun begitu, tidak terdapat perbedaan yang signifikan antara laki-laki dan perempuan dalam melakukan 
pemecahan masalah. Rendahnya tingkat ketelitian mahasiswa laki-laki dalam merencanakan penyelesaian masalah yang mengakibatkan perempuan lebih tepat dalam menemukan solusi dari masalah yang diberikan (Aini, 2017).

\section{KESIMPULAN}

Berdasarkan uraian yang termuat pada hasil penelitian, umumnya mahasiswa perempuan telah membuat representasi simbolik dari masalah yang diberikan. Mereka membuat notasi dan ekspresi matematis untuk mentransformasikan masalah secara simbolik. Berbeda dengan mahasiswa laki-laki. Berdasarkan hasil penelitian mahasiswa laki-laki cenderung langsung mengerjakan soal tanpa menjelaskan interpretasi dari simbol-simbol yang digunakan. Ketika melakukan selesaian soal, mahasiswa laki-laki juga cenderung menggunakan strategi atau metode pengerjaan yang mendasar. Mereka lebih suka menggunakan metode yang telah diperoleh dari pengetahuan sebelumnya daripada menerapakan metode atau strategi selesaian yang baru dipelajari. Sedangkan mahasiswa perempuan lebih berpaku pada apa yang sedang mereka pelajari sekarang.

Pada indikator representasi simbolik yang ketiga yaitu menyelesaikan masalah matematis menggunakan representasi simbolik yang telah dibuat, mahasiswa perempuan lebih unggul dibanding mahasiswa laki-laki. Jika diamati lebih rinci, sebenarnya faktor gender tidak mempengaruhi kecakapan mahasiswa dalam melakukan pemecahan masalah. Hal yang membuat mahasiswa laki-laki mengalami kesalahan dalam menyelesaikan masalah matematis dikarenakan mereka kurang teliti dalam melakukan prosedur perhitungan.

Merujuk pada uraian tersebut, maka mahasiswa perlu dibiasakan membuat simbolisasi dari permasalahan yang diberikan. Mahasiswa perlu memperbanyak latihan pengerjaan soal untuk mengasah kemampuan representasi simboliknya. Selain itu, mahasiswa dalam mengerjakan tugastugas yang diberikan hendaknya lebih menekankan pada proses pengerjaan hingga memperoleh hasil akhir dari selesaian masalah.

Ketika mengajar, Dosen dapat memberikan penekanan pada mahasiswa agar menerapkan metode selesaian masalah sesuai dengan materi yang sedang dipelajari. Hal itu untuk memudahkan dosen dalam mengukur keberhasilan belajar dan pemahaman siswa terhadap materi yang sedang dipelajari. Penelitian berikutnya diharapkan peneliti mampu meninjau representasi matematis yang lainnya baik representasi secara internal maupun eksternal.

\section{UCAPAN TERIMAKASIH}

Ucapan terimakasih kami berikan kepada pihak-pihak yang terlibat dalam penulisan artikel ilmiah ini. Kami berterimakasih kepada Dekan dan Dosen Fakultas Matematika dan IPA, Universitas Negeri Malang yang telah memberikan ijin dan membantu proses penelitian. Kami juga berterima kasih kepada para Mahasiswa yang telah bersedia menjadi responden dan mengikuti alur pengambilan data hingga selesai. Kemudian ucapan terimakasih ditujukan kepada orangtua dan para sahabat yang 
telah mendukung dan memberikan semangat kepada kami sehingga penelitian ini dapat terselesaikan dengan baik.

\section{REFERENSI}

Aini, K. N. (2017). Proses Berpikir Mahasiswa Laki-Laki dan Perempuan dengan Gaya Kognitif Field Independent dalam Memecahkan Masalah. Inspiramatika, 3(1), 16-23. http://ejurnal.unisda.ac.id/index.php/Inspiramatika/article/view/166

Aliyanti, A. P., Putri, O. R. U., \& Zukhrufurrohmah, Z. (2019). Analisis Kesalahan Representasi Simbolik Mahasiswa Dalam Menyelesaikan Soal High Order Thinking Skill. AKSIOMA: Jurnal Program Studi Pendidikan Matematika, 8(3), 382. https://doi.org/10.24127/ajpm.v8i3.2265

Anwar, R. B., \& Rahmawati, D. (2017). Symbolic and Verbal Representation Process of Student in Solving Mathematics Problem Based Polya's Stages. International Education Studies, 10(10), 20. https://doi.org/10.5539/ies.v10n10p20

Anwar, S., Salsabila, I., Sofyan, R., \& Amna, Z. (2019). Laki-Laki atau Perempuan, Siapa yang Lebih Cerdas dalam Proses Belajar? Sebuah Bukti dari Pendekatan Analisis Survival. Jurnal Psikologi, 18(2), 281. https://doi.org/10.14710/jp.18.2.281-296

Aryanti, D., Zubaidah, \& Nursangaji, A. (2013). Kemampuan Representasi Matematis Menurut Tingkat Kemampuan Siswa pada Materi Segi Empat di SMP. Jurnal Pendidikan Dan Pembelajaran, 2(1).

Badan Nasional Standar Pendidikan. (2007). Standar Kualifikasi Akademik dan Kompetensi Guru.

Damayanti, \& Firmansyah, D. (2019). Analisis Kesalahan Siswa dalam Menyelesaikan Soal Aritmatika Sosial. Prosiding Seminar Nasional Matematika Dan Pendidikan Matematika Sesiomadika 2019. https://doi.org/10.36709/jpm.v11i1.10022

Davita, P. W. C., \& Pujiastuti, H. (2020). Analisis Kemampuan Pemecahan Masalah Matematika Ditinjau Dari Gender. Kreano, Jurnal Matematika Kreatif-Inovatif, 11(1), 110-117. https://doi.org/10.15294/kreano.v11i1.23601

Fridgo, T., Yenti, I. N., \& Heriyanti, S. (2016). Analisis Kesalahan Transformasi Soal Pada Kemampuan Representasi Matematis Secara Simbolik. Eksakta, 2, 24-30.

Hardy, Hudiono, B., \& Rahjiin, M. (2015). Pengaruh Gender dan Strategi Pembelajaran Terhadap Kemampuan Pemecahan Masalah Matematis Siswa. Jurnal Pendidikan Dan Pembelajaran Khatulistiwa, 4(9), 1-14. http://library1.nida.ac.th/termpaper6/sd/2554/19755.pdf

Morash, R. P. (1987). Bridge to Abstract Mathematics: Mathematical Proof and Structures. In New York (First Edit). Random House, Inc.

MZ, Z. A. (2013). Perspektif Gender Dalam Pembelajaran Matematika. Marwah: Jurnal Perempuan, Agama Dan Jender, 12(1), 15. https://doi.org/10.24014/marwah.v12i1.511

Pane, N. S. P. S., Jaya, I., \& Lubis, M. S. (2018). Analisis Kemampuan Komunikasi Matematis Siswa pada MateriPenyajian Data di Kelas VII MTs Islamiyah Medan T.P 2017/2018. AXIOM : Jurnal 
Pendidikan Dan Matematika, 7(1), 97-109. https://doi.org/10.30821/axiom.v7i1.1779

Purwanti, K. L. (2013). Perbedaan Gender Terhadap Kemampuan Otak Kanan Pada Siswa Kelas I. Jurnal Sawwa, 9(1), 107-122.

Sabirin, M. (2014). Representasi dalam Pembelajaran Matematika. Jurnal Pendidikan Matematika, 1(2), 33. https://doi.org/10.18592/jpm.v1i2.49

Sanjaya, I. I., Maharani, H. R., \& Basir, M. A. (2018). Kemampuan Representasi Matematis Siswa pada Materi Lingkaran Berdasar Gaya Belajar Honey Mumfrod. Kontinu: Jurnal Penelitian Didaktik Matematika, 2(1), 72. https://doi.org/10.30659/kontinu.2.1.72-87

Sokolowski, A. (2018). The Effects of Using Representations in Elementary Mathematics: Metaanalysis of Research. IAFOR Journal of Education, 6(3), 129-152. https://doi.org/10.22492/ije.6.3.08

Sukmawati, R. (2019). Analisis Kesiapan Mahasiswa Menjadi Calon Guru Profesional Berdasarkan Standar Kompetensi Pendidik. Jurnal Analisa, 5(1), 95-102. https://doi.org/10.15575/ja.v5i1.4789

Suryana, A. (2012). Kemampuan Berpikir Matematis Tingkat Lanjut (Advanced mathematical thinking) dalam Mata Kuliah Statistika Matematika 1. Seminar Nasional Matematika Dan Pendidikan Matematika FMIPA UNY, November, 37-48.

Susilowati, J. P. A. (2016). Profil Penalaran Siswa SMP dalam Pemecahan Masalah Matematika Ditinjau dari Perbedaan Gender. Jurnal Review Pembelajaran Matematika, 1(2), 132-148.

Ulpa, M. (2014). Gender dan Pembelajaran Matematika. Yinyang: Jurnal Studi Islam, Gender Dan Anak, 9(2). 